\title{
Aftercare to chemically addicted adolescents: An exploration of their needs
}

\author{
Authors: \\ Marichen van der \\ Westhuizen ${ }^{1,2}$ \\ Assim H. (Nicky) Alpaslan ${ }^{2}$ \\ Mariana de Jager ${ }^{3}$ \\ Affiliations: \\ ${ }^{1}$ Cape Peninsula University of \\ Technology, South Africa \\ 2Department of Social Work, \\ University of South Africa, \\ South Africa \\ ${ }^{3}$ Department of Social Work, \\ University of Western Cape, \\ Bellville campus, South Africa

\section{Correspondence to:} \\ Marichen van der Westhuizen \\ Email: \\ mvdw@hugenote.com \\ Postal address: \\ PO Box 16, Wellington 7655 , \\ South Africa \\ Dates: \\ Received: 21 Apr. 2011 \\ Accepted: 12 June 2012 \\ Published: 29 Apr. 2013 \\ How to site this article: \\ Van der Westhuizen, M. \\ Alpaslan, A.H., De Jager, M., \\ 2013, 'Aftercare to chemically \\ addicted adolescents: An \\ exploration of their needs', \\ Health SA Gesondheid 18(1), \\ Art. \#599, 11 pages. http:// \\ dx.doi.org/10.4102/hsag. \\ v18i1.599

\section{Copyright:} \\ C 2013. The Authors. \\ Licensee: AOSIS \\ OpenJournals. This work \\ is licensed under the \\ Creative Commons \\ Attribution License. \\ Read online: \\ Scan this QR \\ code with your \\ smart phone or \\ mobile device \\ to read online.
}

Treatment of chemical addiction includes preparation for treatment, formal treatment and aftercare. The latter appears to be a neglected area in service delivery to chemically addicted adolescents, contributing to the high relapse potential following treatment. The current qualitative study aimed at both exploring and describing the aftercare needs of chemically addicted adolescents. The chemically addicted adolescents included in this study received in-patient treatment as well as aftercare, but nonetheless experienced a relapse; necessitating further in-patient treatment. Purposive sampling was implemented to recruit 31 participants between the ages of 14 and 20 years. The sample size was determined by data saturation. Data for this exploratory, descriptive and contextual study were collected by means of narrative inquiry. Tesch's framework for qualitative data analysis was employed and data verification was conducted through Guba's model. The findings illustrated a need to attend to adolescents intrapersonal and interpersonal as well as environmental needs following treatment. The results can provide service providers with focus areas to be included in aftercare services to these adolescents.

Die behandeling van chemiese afhanklikheid sluit die voorbereiding vir behandeling, formele behandeling en nasorg in. Laasgenoemde blyk ' $n$ afgeskeepte area te wees in die lewering van dienste aan chemies-afhanklike adolessente, wat bydra tot die hoë terugvalpotensiaal wat op die behandeling volg. Hierdie kwalitatiewe studie was daarop gerig om die nasorgbehoeftes van chemies-afhanklike adolessente te verken, sowel as te beskryf. Die chemies-afhanklike adolessente wat by hierdie studie ingesluit was het vantevore beide binnepasiëntbehandeling en nasorg ontvang, maar ten spyte hiervan teruggeval; wat verdere binnepasiëntbehandeling genoodsaak het. Doelbewuste steekproefneming is geïmplementeer om 31 deelnemers tussen die ouderdomme van 14 en 20 jaar te werf. Die steekproefgrootte was deur middel van data versadiging bepaal. Data vir hierdie verkennende, beskrywende en kontektuele studie is versamel deur middel van narratiewe ondersoek. Tesch se raamwerk vir kwalitatiewe data-analise is toegepas en dataverifikasie is uitgevoer aan die hand van Guba se model. Die bevindings illustreer ' $n$ behoefte om intrapersoonlike en interpersoonlike, asook omgewingsbehoeftes wat op behandeling volg, aan te spreek as deel van nasorg. Die resultate kan diensleweraars van fokusareas voorsien wat ingesluit kan word in nasorgdienste aan hierdie adolessente.

\section{Introduction and theoretical background}

Substance abuse amongst adolescents remains an international concern in terms of the availability of substances, the link with the increase in the demand for treatment and the negative effects of substance abuse. Chemical substances are readily available to South African adolescents (United Nations Office on Drugs and Crime 2002:26; Zulu 2006:1). To add to the growing concern, the availability of substances relates to the increase in adolescent chemical addiction. An American national survey by the National Institute on Drug Abuse (NIDA) (2006) has shown that 30.0\% of high school students reported exposure to chemical substances, $50.0 \%$ used alcohol (known as a gateway substance that leads to the use of illegal substances) regularly and $26.0 \%$ engaged in binge drinking. In comparison, locally a recent study in the Western Cape found that $11.8 \%$ of the participants identified their homes, $21.3 \%$ identified parties and $24.8 \%$ identified their schools as the major places where they were able to obtain chemical substances (Johnson \& Lazarus 2008:20). The World Health Organization (2008:2) highlighted the need to consider the link between the increase in availability of substances and the increase in the demand for treatment of chemical addiction. This viewpoint is supported by a study by the South African Community Epidemiology Network on Drug Use (2010) that found an increase in demand for treatment of adolescent chemical addiction.

The negative effects of harmful chemical substances, as well as their addictive nature, leads to various individual difficulties such as impaired judgement, memory loss, health problems, 
learning problems and the inability to make positive decisions. Chemical addiction is also associated with crime, accidents and violent behaviour on a social level (Falkowski 2003:65; Njuho \& Davids 2010:35; Youth at the United Nations 2006). These effects lead to specific challenges when dealing with adolescent chemical addiction. The practitioner does not only have to assist with the recovery process, but also has to address or assist in addressing social damages, educational needs and medical needs, as well as consider the potential memory loss and learning difficulties, when developing strategies to assist these adolescents.

\section{Treatment of adolescent chemical addiction}

Treatment of chemical addiction starts with the preparation for treatment (i.e. detoxification and motivation to participate in treatment services) followed by formal treatment (i.e. attending in-patient or out-patient treatment programmes within a specific time-frame) and is concluded with aftercare (i.e. continued support and guidance to develop a sober lifestyle and to reintegrate into society) to prevent relapses (Meyer 2005:292). The latter is an essential component of treatment, as the relapse potential amongst chemically addicted persons is estimated to be between $40 \%$ and $60 \%$, whilst it is between $50 \%$ and $90 \%$ amongst chemically addicted adolescents (CAAs) (NIDA 2006). On the other hand, a $60 \%$ recovery rate was identified when aftercare programmes are utilised (Gordon 2003:11).

Figure 1 clearly refers to the continuum of care for the treatment of chemical addiction and includes areas such as reintegration and aftercare. Services are expected to include all the areas of care (United Nations 2003:8). Reintegration refers to assistance to CAAs to re-establish themselves in the community and includes the focus on networking with schools, churches, families and support groups to prevent relapses (United Nations 2003:15). Relapse following treatment is a common, predictable and preventable part of addiction that has the potential to become a learning process that eventually leads to recovery (Buddy 2003:1; Gordon 2003:3). Effective treatment of adolescent chemical addiction to produce positive change and prevent relapses consists of a treatment period of between 8 and 18 months, and ongoing aftercare services for a following 12 to 24 months (Focus Adolescent Services 2006).

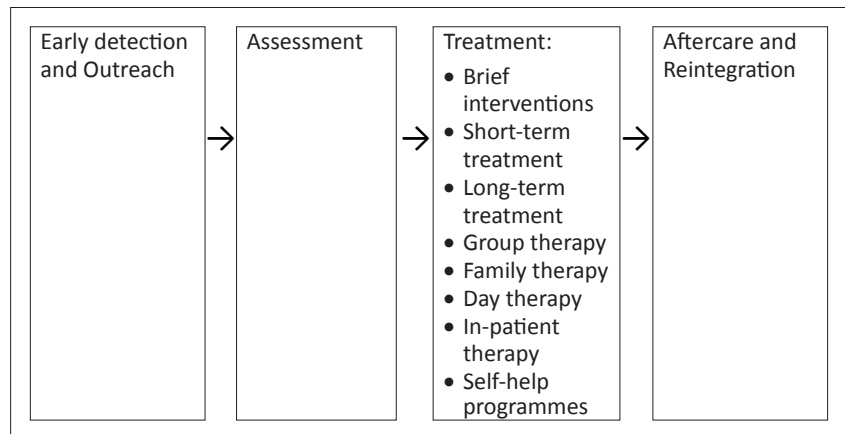

Source: United Nations, 2003, Economic and social commission for Asia and the Pacific United Nations: Office on drugs and crime, United Nations Publications, New York

FIGURE 1: The continuum of care for chemical addiction treatment.
South African legislation makes provision for aftercare as a requirement of adequate treatment. The objectives of the new Prevention of and Treatment for Substance Abuse Act (Act No. 70 of 2008) (Republic of South Africa 2008) prescribes that persons suffering from addiction should have access to professional aftercare services. Adolescent treatment programmes in South Africa, however, vary between 3 weeks and 12 months, whilst feedback from practice indicates a lack of focus on aftercare (Van der Westhuizen 2007, 2010). For example, in Cape Town only $6 \%$ of social service delivery focuses on chemical addiction. Organisations involved in service delivery to people with chemical addictions have expressed feelings of incompetence brought about by restricted resources and a lack of funding (Bozalek, Henderson, Lambert, Collins \& Green 2007:33).

A need to place specific focus on the development of aftercare programmes to prevent relapses amongst CAAs was identified (Van der Westhuizen 2007). However, apart from a study by Van den Berg (2003) in Pretoria, recent studies do not focus on aftercare programmes that link aftercare services with the specific needs of the clients (Brandt \& Delport 2005:163-174; Johnson \& Lazarus 2008:20; Noyoo, Patel \& Loffell 2006:97). To add to the growing debate, researchers such as Desai and Potter (2006:52) stress that adolescents' voices are seldom heard and so by studying their needs, interventions can be planned accordingly. The current study is aimed at addressing this contemporary treatment reality to develop a more comprehensive and contextually richer description and understanding of especially the aftercare needs of CAAs to support specialised services providers with contextually appropriate recommendations to be included in future aftercare programmes.

\section{Definition of key concepts}

For the purpose of this research various concepts deserve closer attention. Firstly, an adolescent will be defined as a person between the ages of 11 and 21 years (Louw \& Louw 2007:281). Secondly, aftercare services refers to ongoing support to addicted persons and their families following formal treatment to increase the recovery potential and thereby limiting the need for re-admission to treatment centres (Rosenberg 2008:126). The third concept is chemical addiction, which is characterised by a compulsion to consume chemical substances, development of a tolerance for the chemical substances abused and the experience of withdrawal symptoms when the abuse of substances is interrupted. The addiction affects the physical, social, emotional and spiritual well-being of the addicted person (Keegan \& Moss 2008:149). Fourthly, relapse prevention refers to a learning process where chemically addicted persons learn how to live without chemical substances and to protect themselves from harmful situations, thereby preventing relapses (Falkowski 2003:43-44). The last concept is treatment of adolescent chemical addiction, which should include detoxification and preparation and motivation for treatment, the actual treatment, as well as aftercare services to ensure that they develop the relevant skills to maintain sobriety (Meyer 2005:292-293). 


\section{Problem statement}

The problem statement for this study (based on the Introduction and theoretical background section above) was conceptualised as follows: the literature studied provided a clear picture of the physical and emotional damage caused by chemical substances, treatment costs and the potential to impair functioning in the adult life cycle (Falkowski 2003:65). The increase in adolescent substance abuse is highlighted as a challenge to adapt professional services to address this problem effectively (Fisher \& Harrison 2005:148). Additionally, it is argued that treatment should include detoxification, treatment programmes and aftercare (Meyer 2005:292). However, aftercare services seem to be excluded from the current services provided to CAAs. Research endeavours, focusing on the lack of existing aftercare programmes or practice guidelines, as well as the specific needs of CAAs following treatment, have the potential to address the concern regarding adolescent chemical addiction in a relevant manner. Intervention based on research findings should therefore include a specific aftercare service following in-patient or out-patient treatment, in order to offer adolescents suffering from chemical addiction ongoing and adequate support in an effort to maintain sobriety and to prevent relapse. These services should be based on the needs of the said group to ensure sustainable change following treatment. The researchers therefore hoped to make a conceptually sound contribution to the planning of aftercare services and thereby also address the recovery potential of CAAs through this research.

\section{Aims of the study}

The focus of this research study was on the aftercare component related to the treatment of adolescent chemical addiction. The above research problem resulted in the following research question: 'What are the specific aftercare needs of chemically addicted adolescents (CAAs) following treatment?' The aim of this research was to develop an understanding of the aftercare needs of CAAs and to make recommendations to assist service providers involved with service delivery to CAAs with the future planning and execution of aftercare services. The research objectives were therefore to explore and describe the specific aftercare needs of relapsed CAAs following treatment and - based on this article's findings - to provide service providers with recommendations to be included in aftercare programmes.

\section{Research method and design}

A qualitative research approach was employed to develop a deeper conceptual understanding of the aftercare needs of CAAs (Donalek \& Soldwisch 2004:354) in order to ensure sound recommendations for future planning and execution of services. The exploratory research design was employed, as both the current literature (cf. Falkowski 2003:65; Njuho \& Davids 2010; United Nations 2003:15) and previous completed studies (cf. Brandt \& Delport 2005:163-174; Johnson \& Lazarus 2008:20; Noyoo, Patel \& Lofell 2006:97;
Van den Berg 2003) indicate a need to further elucidate the specific aftercare needs of CAAs (Babbie \& Mouton 2007:79). In order to contribute to a better objective understanding of these needs, as experienced by CAAs (Fox \& Bayat 2007:8), the descriptive research design was employed.

The target population for this study was defined as follows: all CAAs in the Western Cape Province of South Africa who experienced a relapse after in-patient treatment. A sample of the population to enhance the validity of the study (Walliman 2001:232) was selected based on the following criteria for inclusion: CCAs who had previously undergone in-patient treatment and had contact with an social worker following treatment, who relapsed thereafter and who subsequently re-entered in-patient treatment programmes in the Western Cape.

In order to ensure that the participants were selected on the basis of relevancy to the topic, purposive sampling as a technique of the non-probability sampling method was employed to provide the researchers with a sample to access some specialised and contextually relevant insights into the phenomena of aftercare needs of CAAs (Fox \& Bayat 2007:54). The researchers made use of the above sampling criteria to make contact with adolescents who were viewed as best equipped to explore the research question. Access was obtained through the support of adolescent in-patient treatment centres. Both the treatment centres and the parents of the participants provided consent for the adolescents to partake in the study. The sample size for this study was determined by data saturation, once the information became repetitive (Bless, Higson-Smith \& Kagee 2006:107-108). Data saturation was observed after 27 narratives were completed. The researchers continued to collect data from an additional four participants to ensure that data saturation indeed took place. Data collection was terminated after 31 narratives.

The researchers collected the data from the adolescent participant sample group by means of 31 written narratives, which also served as a means of data recording. Participants were requested to write about: 'The things social workers can help me with to maintain my sobriety after treatment.'

Tesch's framework for data analysis (Creswell 2009:186) was employed. It assisted the researchers to use a coding system, based on eight steps, through which the different themes, subthemes and categories could be identified. Data verification was conducted through Guba's model (Krefting 1991:214-222) including peer examination, a dense description of the research methodology and the use of an independent coder.

\section{Results}

The biographical particulars of the 31 relapsed CAAs in the Western Cape who participated in this study are presented in Table 1. 
TABLE 1: Demographic details of the chemically addicted adolescents who participated in this study.

\begin{tabular}{|c|c|}
\hline Category & $n$ \\
\hline \multicolumn{2}{|l|}{ Gender } \\
\hline Male & 31 \\
\hline \multicolumn{2}{|l|}{ Age groups } \\
\hline 14 years & 3 \\
\hline 15 years & 4 \\
\hline 16 years & 6 \\
\hline 17 years & 9 \\
\hline 18 years & 2 \\
\hline 19 years & 1 \\
\hline 20 years & 6 \\
\hline \multicolumn{2}{|l|}{ Racial groups } \\
\hline African & 5 \\
\hline Mixed race & 21 \\
\hline Asian & 3 \\
\hline White & 2 \\
\hline \multicolumn{2}{|l|}{ Language } \\
\hline English & 6 \\
\hline Afrikaans & 20 \\
\hline Xhosa & 3 \\
\hline Sotho & 2 \\
\hline \multicolumn{2}{|l|}{ Parental use of chemical substances } \\
\hline Alcohol & 13 \\
\hline $\begin{array}{l}\text { Other chemical substances (marijuana, mandrax, } \\
\text { methamphetamine) }\end{array}$ & 6 \\
\hline \multicolumn{2}{|l|}{ Education completed } \\
\hline Grade 4 & 2 \\
\hline Grades 5-7 & 8 \\
\hline Grades 8-10 & 13 \\
\hline Grade 11 & 7 \\
\hline Grade 12 & 1 \\
\hline \multicolumn{2}{|l|}{ Participants' chemical substances of choice } \\
\hline Methamphetamine & 18 \\
\hline Alcohol & 4 \\
\hline Marijuana & 7 \\
\hline Heroin & 1 \\
\hline Cocaine & 1 \\
\hline \multicolumn{2}{|l|}{ Treatment opportunity } \\
\hline Second & 29 \\
\hline Third & 2 \\
\hline
\end{tabular}

$n$, number of relapsed chemically addicted adolescents.
The participants in this study gave detailed descriptions of their aftercare needs in terms of aspects they would like to be assisted with during aftercare. For the purpose of this article, quotations are presented verbatim. The participants' responses were presented in an integrated manner, highlighted by the use of the participants' reference numbers (e.g. P1 - P31). However, quotations made in Afrikaans, were translated into English by an accredited editor and linguist.

The findings illustrated a need to attend to intrapersonal and interpersonal, as well as environmental needs following treatment. Table 2 illustrates the theme, sub-themes and categories that were identified during the analysis of the qualitative data

The findings have been presented below in terms of the thematic discussion of the qualitative data, followed by a literature review. The main theme was those aspects with which CAAs would like to be assisted during aftercare.

\section{Aspects with which chemically addicted adolescents would like to be assisted during aftercare}

\section{Sub-theme 1: Intrapersonal needs of chemically addicted adolescents to be addressed in aftercare}

The categories identified within this sub-theme are listed below.

\section{The need to change old habits relating to their addiction}

The participants described a need to change habits typically associated with their addiction and specifically identified theft, dishonesty and swearing as areas that need continued attention in aftercare:

'I don't want to go to jail for stealing and she [referring to the social worker] must help me to live right.' (P8, Male, 16 years old)

'She [referring to the social worker] must help me to stop lying and stealing and swearing.' (P14, Male, 17 years old)

TABLE 2: Summary of the findings.

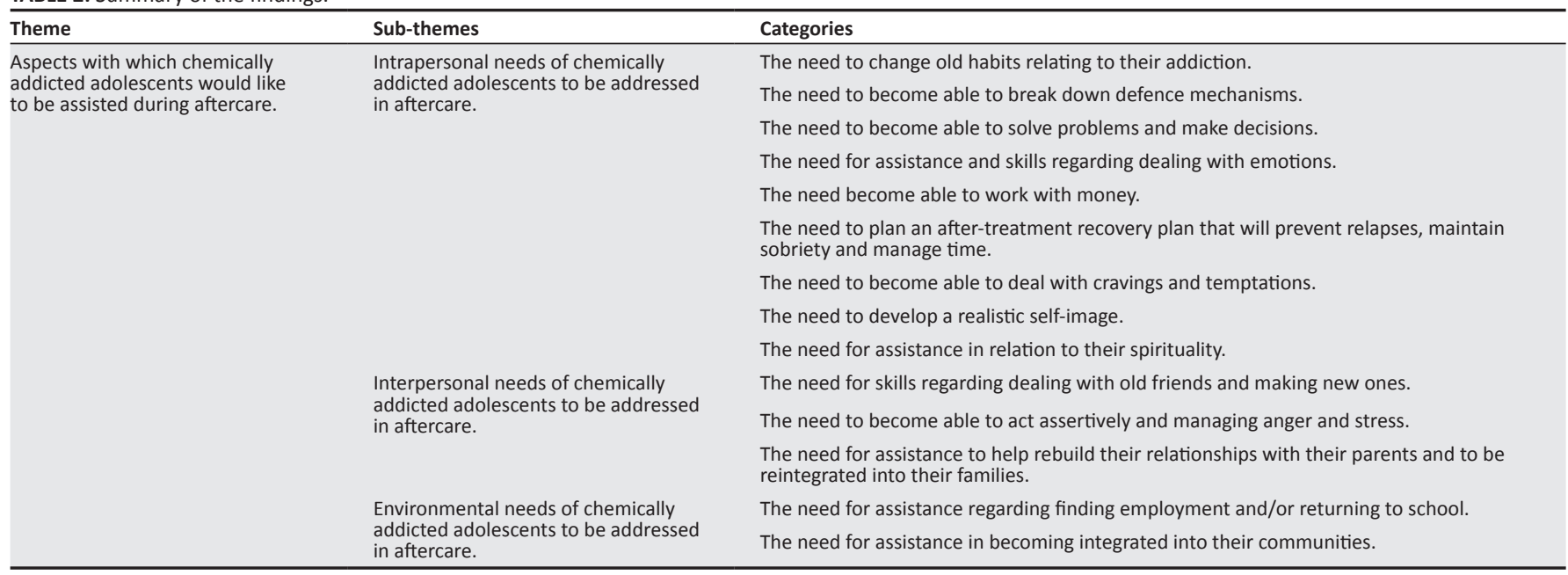


'I am going to struggle to do the right things instead of wrong things [referring to substance-related activities].' (P31, Male, 20 years old)

\section{The need to become able to break down defence mechanisms}

Also related to old behaviour, as described in the category above, the participants mentioned lying and covering up as defence mechanisms that should be addressed in aftercare, as they were used to maintain the abovementioned old behaviour:

'I want to stop covering up and lying.' (P2, Male, 17 years old)

'I will just lie and that is not good if I want to stay sober.' (P26, Male, 17 years old)

\section{The need to become able to solve problems and make decisions}

The following statements highlight a need to discuss problems other than their addictions, and the need for problem-solving:

'She [referring to the social worker] must help me with my problems.' (P1, Male, 14 years old)

'And she [referring to the social worker] must not just talk of addiction, but also about my other problems.' (P12, Male, 18 years old)

'I want to tell her [referring to the social worker] when I have a problem and then she must show me what to do.' (P8, Male, 16 years old)

\section{The need for assistance and skills regarding dealing with emotions}

Another aspect to address through aftercare intervention requested by the participants was assistance with and skills for dealing with emotions, as evidenced by statements such as:

$$
\text { 'It will help me to share what I feel.' (P18, Male, } 20 \text { years old) }
$$

Fear was identified as an emotion with which a participant needed assistance:

'I need them [referring to the social workers] to help me with being afraid. I am afraid to go home, because I know I am going to get killed.' (P22, Male, 16 years old)

Other participants expressed feelings of guilt as a result of the addiction and the problems caused as a result of the addiction:

'I feel bad about all the bad things I did and do not know how to handle it.' (P3, Male, 17 years old)

Expressing a wish to deal with the feeling of guilt, a participant commented as follows:

'I wish my family can allow me to give them the money [referring to money stolen from the parents and siblings] to make things right.' (P28, Male, 20 years old)

\section{The need become able to work with money}

The participants reported that having money available triggered a relapse:

'Money is almost like something that led me back to the drugs.' (P1, Male, 14 years old)
'I was alone and bored. So, I had money and all I could think of, was to go and buy drugs.' (P17, Male, 15 years old)

Based on the abovementioned link between money and relapse, a participant requested assistance to learn how work with money:

'If I get a job, then I wish she [referring to the social worker] can help me with the money.' (P5, Male, 20 years old)

\section{The need to plan an after-treatment recovery plan that will prevent relapses, maintain sobriety and manage time}

Related to the comment about boredom in the above category, the participants also reported that an after-treatment plan should assist them to manage time. As such, the following remark by a participant highlights the need for assistance to be able to develop a new lifestyle:

'She [referring to the social worker] must help me to adjust to a sober life.' (P25, Male, 16 years old)

In order to do so, the participants' utterances below refer to the need for assistance to develop a recovery plan and in practising their new behaviour and avoiding contact with temptations:

'She [referring to the social worker] must help me to stay busy.' (P4, Male, 17 years old)

'She [referring to the social worker] must tell me how to enjoy life drug free.' (P7, Male, 17 years old)

'I need a social worker for aftercare to help me to go on with this sober life.' (P30, Male, 14 years old)

The participants referred to the value of hobbies and sports in order to fill time and, in so doing, prevent relapses and maintain sobriety:

'To work out a plan and get a hobby. Example: sport.' (P9, Male, 16 years old)

\section{The need to become able to deal with cravings and temptations}

A part of this relapse plan mentioned in the above category, according to the participants, is to assist them to deal with cravings and temptations. The participants specifically requested assistance from social workers about how to deal with cravings when they remarked:

'The social worker should be someone I could call when I have cravings or on the edge of relapsing.' (P29, Male, 20 years old)

'She [referring to the social worker] must help me to deal with these cravings.' (P25, Male, 16 years old)

'And to help me to deal with the desire to use drugs.' (P19, Male, 15 years old)

\section{The need to develop a realistic self-image}

The need to develop a positive self-image was illustrated by the following statements:

\section{'I am unsure of myself.' (P17, Male, 15 years old)}

'I want to know my good things. She [referring to the social worker] must help me figure out what I am good at.' (P15, Male, 16 years old)

'She [referring to the social worker] must tell me when I do a good thing and when I do a bad thing.' (P19, Male, 15 years old) 
Relating to self-worth, a participant made the following comment that indicate a need to feel worthy:

'I need to forgive myself and others must forgive me for the bad things I did.' (P6, Male, 20 years old)

\section{The need for assistance in relation to their spirituality}

The following remarks point to the fact that participants feel a need for assistance in relation to their spirituality:

'And I want to work on my relationship with God.' (P23, Male, 17 years old)

'I am going to struggle with going to church.' (P27, Male, 19 years old)

\section{Sub-theme 2: Interpersonal needs of chemically addicted adolescents to be addressed in aftercare}

The categories identified within this sub-theme are listed below.

\section{The need for skills regarding dealing with old friends and making new ones}

In their narratives, the participants requested assistance and identified a need for skills that would enable them to deal with peers who still use chemical substances:

'I don't know what I will do with my friends who use drugs.' (P10, Male, 17 years old)

'They will continue to come to my house and force me to use it.' (P24, Male, 17 years old)

'I am afraid that they will ask me to use drugs. Because then I will just feel like using.' (P11, Male, 16 years old)

'The things bothering me in my community are my old friends and the temptations.' (P13, Male, 15 years old)

Apart from assistance and skills on how to deal with former friends, the following statements illustrate awareness of the necessity of making new friends, as well as the lack of skills on how to establish and maintain new friendships:

'I need help to find sober friends and to stay away from my friends who use drugs.' (P15, Male, 16 years old)

'And help with choices to make new friends that can help me.' (P21, Male, 15 years old)

'And she [referring to the social worker] must show me how to make new friends.' (P3, Male, 17 years old)

\section{The need to become able to act assertively and manage anger and stress}

The participants also requested assistance and expressed a need for skills during aftercare on how to act assertively in an interpersonal context and how to manage anger and stress:

'I must learn how to say no to my friends.' (P16, Male, 18 years old)

'And I struggle when people tell me to do wrong things. The social worker must help me with this.' (P20, Male, 14 years old)

'I am not so strong that I can tell them no I don't want to use.' (P13, Male, 15 years old)

'I also want to know what to do when I stress.' (P1, Male, 14 years old)
'I feel like I will become crazy when I stress when people tell me I used when I did not.' (P27, Male, 19 years old)

'And I need to stop fighting.' (P21, Male, 15 years old)

'I must also learn to handle my anger and not be ugly with other people.' (P23, Male, 17 years old)

'She [referring to the social worker] must help me not to be rude to people and not to hate them.' (P9, Male, 16 years old)

'She [referring to the social worker] must help me with my anger problem. I fight a lot.' (P31, Male, 20 years old)

The need for assistance to help rebuild their relationships with their parents and to be reintegrated into their families

The need for assistance to rebuild relationships with parents during aftercare became clear as the participants expressed concern about the amount of support they would receive when they went home:

'And my parents will not support me.' (P2, Male, 17 years old)

'I have problems with my parents and need help with it.' (P27, Male, 19 years old)

The participants also need assistance to restore parent-child relationships and bonds. The following storylines refer to this:

'I will ask her [referring to the social worker] to help me with my relationship with my biological dad.' (P20, Male, 14 years old)

'I need help to get along with my parents.' (P11, Male, 16 years old)

'I have problems with my parents and need help with it.' (P27, Male, 19 years old)

'I want her [referring to the social worker] to help me that my parents understand me and accept me for who I am.' (P29, Male, 20 years old)

The following utterances refer to the loss of trust between the parents and the CAA as a result of the addiction. The participants asked for help to restore the trust between them and their parents:

'I would love for her [referring to the social worker] to help me build the trust again with my family.' (P6, Male, 20 years old)

'And my parents will think I am still using and accuse me of things.' (P14, Male, 17 years old)

The need to restore communication and to address the need for conflict management skills with their parents in order to become part of the family again was reported as follows:

'She [referring to the social worker] must help me to talk to my parents.' (P8, Male, 16 years old)

'I worry about fights with my parents and all that stress.' (P21, Male, 15 years old)

Additionally, the participants reported a concern regarding abuse of substances by family members that could threaten their recovery processes, as well as their successful reintegration into the family:

'I need help with my home problems. My dad also uses drugs.' (P13, Male, 15 years old)

'My younger brother also uses drugs.' (P27, Male, 19 years old) 
Apart from a need for assistance from social workers to rebuild their relationships with their parents and to be reintegrated into their families, the participants also expressed the need for assistance with being integrated into their communities.

\section{Sub-theme 3: Environmental needs of chemically addicted adolescents to be addressed in aftercare}

The categories identified within this sub-theme are listed below.

\section{The need for assistance regarding finding employment and/or returning to school}

The following statements are representative of the participants' expressed need to be supported to be able to return to school:

'She [referring to the social worker] must help me to get back in school.' (P11, Male, 16 years old)

'I need her [referring to the social worker] to help me to go back to school. I need them to take me back or else I will not find a job.' (P8, Male, 16 years old)

'It will be nice if she [referring to the social worker] can help me to find a job.' (P24, Male, 17 years old)

\section{The need for assistance in becoming integrated into their communities}

With regard to reintegration into the community, the participants stated that they need social workers to help them in this regard, but those social workers should know their communities and the challenges they face within them. The following storylines point to this:

'The social worker must give me tips of how to cope in my community and motivate me to stay sober.' (P28, Male, 20 years old)

'She [referring to the social worker] must know my community. She must go with me to my community so she can see what I deal with.' (P3, Male, 17 years old)

'It will help her [referring to the social worker] to understand my side. My community is difficult.' (P5, Male, 20 years old)

In addition to understanding the challenges in the community, a participant also requested that social workers must be aware of support systems in their communities:

'She [referring to the social worker] must know where I can find good friends in my community.' (P19, Male, 15 years old)

The participants also expressed a need for social workers for assistance and practical support to be linked to support groups and Narcotics Anonymous (NA):

'And she [referring to the social worker] must take me to NA meetings.' (P25, Male, 16 years old)

'I need help to get to the support groups.' (P20, Male, 14 years old)

In the previous sub-theme, namely Interpersonal needs of chemically addicted adolescents to be addressed in aftercare, mention was made of the mistrust between the participants and their parents resulting from the substance abuse. From the accounts below, the mistrust of the participants from the side of the community became apparent:
'I will appreciate the acceptance and trust in the community.' (P1, Male, 14 years old)

'I will need help there because I know it will be difficult for some of them to see that I am a new person.' (P7, Male, 17 years old)

The participants reported that the availability of substances was experienced as a stressful aspect in their recovery process and that they would like assistance in this regard:

'Where I live drugs are everywhere.' (P18, Male, 20 years old)

'I need to know how to ignore all the drugs in my community.' (P23, Male, 17 years old)

'I must also learn how to know the wet places [places where substances are available] in my community.' (P26, Male, 17 years old)

In addition, the reality of the link between substance addiction and gangs in the Western Cape (Ganga 2007) was confirmed by the participants through the following statements:

'What does the social worker know about gangs and the numbers?' (P4, Male, 17 years old)

'When I go home the gangs will kill me.' (P12, Male, 18 years old)

'She [referring to the social worker] must help me to deal with the old friends and the wet places.' (P10, Male, 17 years old)

\section{Ethical considerations}

Informed consent was obtained by means of consent forms signed by participants, the treatment centres, and parents and/or guardians. Protection from harm to participants was ensured through safe environments in which data were collected and referrals to therapists afterwards. The right to privacy and confidentiality of the data was addressed as participants were not forced to share their experiences and were informed that they could withdraw from the study at any time. Furthermore, participants were informed that only the researchers and independent coder would have access to the transcripts.

\section{Trustworthiness}

The trustworthiness of the qualitative data obtained through this study was based on Guba's model (Krefting 1991:214-222), addressing the truth value, applicability, consistency and neutrality of this research study. The researchers established confidence in the truth of the findings through the strategy of credibility by using interviewing techniques associated with qualitative data collection, triangulation of theory and peer examination. In order to enhance the applicability, the purposive sampling technique was employed. Triangulation (of theory), peer examination and an independent coder were used to establish consistency. Neutrality was based on the data obtained from the transcripts, which included the field notes, as well as the written narratives.

\section{Theoretical discussion of themes}

Regarding the intrapersonal needs of CAAs to be addressed in aftercare, Becker (2005:169) notes that in dealing with old behaviour that maintains addiction, addicts need to be assisted in developing coping skills that will create new 
behaviours. The CAA must be assisted to become resilient by replacing old habits with new ones. Resilience provides hope and leads to the capacity to continue further growth and development, despite high risks and adversity (Saleeby 2006:198). Connected to being assisted to develop skills to change old habits relating to the addiction, is a need for assistance and skills to break down defence mechanisms. Becker (2005:125) explains that defence mechanisms are used to find shelter from real-life challenges. Defence mechanisms are therefore often mistaken for resistance. Denial is often interpreted as lying and is used when the addict refuses to admit the addiction or the consequences thereof (Caroufek 2007:4-6). A defence mechanism related to covering up is projection, which takes place when the addict projects the reason for his or her situation and keeps others responsible for the problem (Sheafor \& Horejsi 2006:273). Regarding the impact of defence mechanisms on the recovery potential, Gordon (2003:18) warns that defence mechanisms impact negatively on the level of motivation to commit to aftercare.

The importance of the development of problem-solving and decision-making skills is discussed by Louw and Louw (2007:307), who note that the impact of chemical substances on the CAA leads to the inability to comprehend the long-term consequences of choices that he or she will make. Neuland (2006:37) postulates that emotions influence the way CAAs think and alter their perceptions of themselves and the world in which they live, thereby influencing the way they behave in terms of choices and reactions on problematic situations. Focusing on dealing with emotions, Page and Page (2003:53-59) suggest that the following aspects be included in aftercare services: the identification of own emotions and other people's emotions, impulse control and delayed gratification, and the ability to calm themselves.

The literature confirms that the ability to work with money (i.e. budgeting and financial planning) should form part of the key areas to be addressed in relapse prevention (Fisher \& Harrison 2005:162-169; United Nations 2003:24-25). The need to develop financial-planning skills is based on two reasons. Firstly, CAAs and their families have suffered financial losses because of their addiction, which result in feelings of guilt and a need to repair this damage (as described in Sub-theme 1). Secondly, these young people were previously focused on securing funds for the chemical substances. Therefore, the ability to plan financially was not developed and could lead to stress (Fisher \& Harrison 2005:162-169).

The importance of time-management as part of a recovery plan is also noted by Fisher and Harrison (2005:162-169), who advise that in recovery, addicts should learn to divide their time between work or school, rest and socialisation as part of relapse prevention. Keegan and Moss (2008:100) note that many addicts suffer from multiple relapses, as they need to commit not only to treatment, but also to recovery. A recovery plan provides structure to assist in them in accepting the continued danger of relapsing and cravings as a reality of their daily lives. Falkowski (2003:51) asserts that intense cravings for the good feeling provided by the substance are ongoing. The adolescents therefore need coping skills and a sense of purpose to withstand these cravings.

Additionally, self-worth plays a role in resilience that could contribute to the management of cravings (Saleeby 2006:198). A realistic self-image amongst adolescents is characterised by a sense of competence, worthiness and belonging. On the other hand, a negative self-image may result in substance addiction and juvenile delinquency (Bezuidenhout 2008:133-135). Page and Page (2003:45-49) postulate that the self-image is enhanced through the development of a sense of self-worth. Spirituality also relates to a sense of self that provides an addicted person with a purpose, a belief in the potential to change and grow, and affects the way the person perceives the world. It is a continuous process that assists in making changes (Lessa \& Scanlon 2006:14).

The findings related to the interpersonal needs of CAAs are supported by various authors. Falkowski (2003:46) identifies poor social skills and affiliation with substance-using peers as factors that maintain addiction and cause relapses to occur. Peer pressure can be direct or indirect. Direct pressure occurs when peers expose the CAA in recovery to chemical substances and use verbal and non-verbal communication to bring the message across that the adolescent will only be accepted in the peer group if he or she uses the chemical substance. Alternatively, indirect pressure relates to environmental cues, such as paraphernalia, language and music, which are associated with the use of chemical substances (Elliot-Wright 2004:31). Assertiveness therefore is a valuable skill to enable the CAA in recovery to deal with temptations from friends (Jarvis, Tebutt, Mattick \& Sand 2005:104). Fuller (2007:77) concurs that adolescent stress leads to a feeling of helplessness and has a lot to do with a lack of assertiveness regarding social and peer pressure. Page and Page (2003:280) note that the inability to deal with stress leads to feelings and expressions of anger and frustration. These authors advise that CAAs should learn that anger is not an inappropriate feeling, but that it is their responsibility to manage anger.

Straussner and Fewell (2006:3) are of the opinion that the family should be viewed as an integral part of aftercare services, considering the facts that the addiction occurred in the family, that the family could have participated in and perpetuated the addiction, that the addiction harmed the family, and that the family is an important potential treatment and recovery resource. In addition, the lack of trust in families leads to a perception of 'my parents do not trust me anyway' (Brand \& Delport 2005:165).

Both Falkowski (2003:46) and Bezuidenhout (2008:133-135) identify failure in school performance as well as school pressure as environmental needs of CAAs to be addressed in aftercare in order to prevent relapses from occurring.

Mans (2000) argues that addicted adolescents' continued search for emotional release and acceptance by society, as well as a lack of coping skills, impact negatively on their 
reintegration into society. A lack of acceptance by the community is associated with labelling, which can alienate adolescents, putting them at risk and therefore contributing to relapsing (Brendtro, Brokenleg \& Von Bockern 2002:7).

Regarding multiple resources, Fuller (2007:109) concurs that adolescents need to develop a sense of belonging, which could be obtained from the family, school, peers and the community. Focusing on the community, Falkowski (2003:46) notes that strong bonds with social institutions could contribute to aftercare services and prevent relapses from occurring. The literature indicates the following advantages regarding self-help groups:

- Self-help groups provide CAAs with role models to assist them in forming new beliefs regarding substance abuse (Brandt \& Delport 2005:168).

- Self-help groups assist CAAs to form new, healthy interpersonal relationships and to learn to function in the community (Focus Adolescent Services 2006:6).

- Self-help groups for the family, such as AL-ANON, NARANON and Tough Love ensure that the family members understand the addiction, as well as the recovery process, and that they receive support regarding their own experiences of the addiction in the family (Athealth. com 2006:6).

In conclusion, the availability of chemical substances, as well as the tolerance of the use of chemical substances in the community poses a risk to CAAs following treatment (Bezuidenhout 2008:133-135; Falkowski 2003:46) and should be a focus area in aftercare services.

\section{Limitations of the study}

During the theme analysis, it became evident that the descriptions provided by the research participants can be described as concrete and need-based. One of the reasons for this aspect may be that the participants in this research study were substance-free for short periods: 10 were sober for a period of 6 weeks, whilst 21 participants were sober for 4 weeks. In addition, most of the participants were addicted to methamphetamine, followed by marijuana. Although the exact permanent damage caused by methamphetamine has not yet been determined, preliminary tests indicate memory and speech problems, physical weakness and strokes as problems associated with the use of this substance $(\mathrm{Yu}$, in Pienaar 2006:15). The researchers were cognisant of the fact that responses may have been influenced by these factors. All the participants were male adolescents, thus excluding the voice of female CAAs who had relapsed.

\section{Recommendations}

Based on the findings described above, it is recommended that the planning and implementation of aftercare services to CAAs should focus on the development and internalisation of skills to assist them in their efforts to recover from chemical addiction. It is also recommended that services include the family and community resources. Specific attention should be placed on the aspects described below.
Regarding the development of intrapersonal and interpersonal skills, service providers should place emphasis on:

- Changing the former habits relating to their addiction through introducing new habits and activities.

- Breaking defence mechanisms by means of rewarding honesty and efforts made towards sobriety.

- Dealing with old friends and making new ones.

- Acting assertively in interpersonal contexts.

- Managing anger and stress that could trigger relapses.

- Solving problems to prevent the CAA from making wrong choices that could lead to a relapse.

- Making decisions regarding the development of a recovery plan, managing time, making friends and working with money.

- Dealing with emotions to become able to identify emotions and find ways to express emotions in a healthy manner.

- Dealing with cravings and temptations through thoughtstopping techniques and the development of a recovery lifestyle.

- Developing a realistic self-image that relates to a sober lifestyle.

Aftercare services should also include the family and community resources in the following ways:

- Involvement of religious organisations to deal with matters relating to spirituality.

- Networking with treatment centres to ensure continuity of services that include preparation for treatment, formal treatment and aftercare.

- Networking with support groups to assist the CAA and their families with aftercare and reintegration into communities.

- Involvement of community resources to assist CAAs with finding employment and returning to school.

- Rebuilding their relationships with parents and reintegrating with their families.

- Addressing the availability of substances in communities by means of an inter-profession approach.

It is hoped and envisaged that the inclusion of these aspects in aftercare programmes to CAAs would contribute to their successful reintegration into communities and families following formal treatment and that it would assist in preventing relapses.

\section{Conclusion}

The research question that guided the focus of this study was: What are the specific aftercare needs of CAAs following treatment? The aim of this research endeavour was therefore to develop a better understanding of the aftercare needs of CAAs to provide service providers with recommendations to be included in aftercare programmes. It was envisaged that these recommendations would contribute to ongoing efforts to address adolescent chemical addiction and to prevent relapses following formal treatment. In order to achieve the aim, data were collected from 31 CAAs in the Western Cape, who relapsed after in-patient treatment and went back to inpatient treatment centres. The qualitative research approach, 
together with the exploratory and descriptive research designs, enabled the researchers to answer the research question. The reported needs were recorded by means of written narratives.

The data resulted in a description and presentation of a primary theme: aspects with which CAAs would like to be assisted during aftercare. Three sub-themes described the content of the theme in terms of, (1) intrapersonal needs, (2) intrapersonal needs and (3) environmental needs of CAAs to be addressed in aftercare. The first sub-theme related to the intrapersonal needs resulted in nine categories focusing on the need for assistance in: breaking old habits relating to addiction, breaking down defence mechanisms, solving problems and making decisions, dealing with emotions, gaining the ability to work with money, gaining the ability to plan an after-treatment recovery plan that will prevent relapses, maintaining sobriety and managing time, gaining the ability deal with cravings and temptations, developing a realistic self-image, and working on spiritual needs.

The second sub-theme, focusing on interpersonal needs, was presented in terms of three categories, focusing on needs for skills regarding dealing with old friends and making new ones, to acting assertively and managing anger and stress, and assistance in helping rebuild their relationships with their parents and to be reintegrated into their families. Lastly, the third sub-theme focused on environmental needs that were presented in two categories, focusing on the need for assistance regarding finding employment and/or returning to school and becoming integrated into their communities.

\section{Acknowledgements Competing interests}

The authors declare that they have no financial or personal relationships which may have inappropriately influenced them in writing this article.

\section{Authors' contributions}

A.H.A. (University of South Africa) was the project leader. M.A.v.d.W. (Huguenot College), A.H.A. and M.S.d.J. (University of the Western Cape) were responsible for the development of the research plan, whilst M.A.v.d.W. conducted the research project. All three authors were involved in the data analysis process, whilst M.A.v.d.W. wrote the manuscript.

\section{References}

Athealth.com, 2006, Getting the facts about adolescent substance abuse and treatment, viewed 03 April 2006, from http://www.athealth.com/Consumer/ adolescentsufacts.htm

Babbie, E. \& Mouton, J., 2007, The practice of social research, Oxford University Press, Cape Town.

Becker, L., 2005, Working with groups, Oxford University Press, Cape Town.

Bezuidenhout, F.J., 2008, A reader on selected social issues, 4th edn., Van Schaik Publishers, Pretoria.
Bless, C., Higson-Smith, C. \& Kagee, A., 2006, Fundamentals of social research methods - An African perspective, 4th edn., Paarl Printers, Cape Town.

Bozalek, V., Henderson, N., Lambert, W., Collins, K. \& Green, S., 2007, 'Social services in Cape Town: An analysis using the political ethics of care', Social Work/ Maatskaplike Werk 43(1), 28-40.

Brandt, C.J. \& Delport, C.S.L., 2005, 'Theories of adolescent substance use and abuse', Professional Journal for Social Work 41(2), 163-175.

Brendtro, L.K., Brokenleg, M. \& Von Bockern, S., 2002, Reclaiming youth at risk, Our hope for the future, rev. edn., Indiana National Education Service, Bloomington.

Buddy, T., 2003, Addiction relapses similar to other chronic diseases, viewed 02 May 2007, from http://alcoholism.about.com/cs/relapse/a/blcaron030804.htm

Caroufek, J., 2007, 'Breaking free from addictions', The Good News 12(6), 4-7.

Creswell, J.W., 2009, Research design: Qualitative, quantitative and mixed approaches, 3rd edn., Sage Publishers, Thousand Oaks.

Desai, V. \& Potter, B.P., 2006, Doing development research, Sage Publishers, London.

Donalek, J.G. \& Soldwisch, S., 2004, 'An introduction to qualitative research methods', Urologic Nursing 24(V), 354-356. PMid:15446383

Elliot-Wright, S., 2004, Amphetamine and ecstasy, White-Thomson Publishers Ltd, Lewes.

Falkowski, C.L., 2003, Dangerous drugs, 2nd edn., Hazelden Foundation, Center City. PMCid:166956

Fisher, G.L. \& Harrison, T.C., 2005, Substance abuse, 3rd edn., Pearson Education Ltd, Boston.

Focus Adolescent Services, 2006, Drug and teen substance abuse, viewed 03 April 2006, from http://www.focusas.com/SubstanceAbuse.html

Fox, W. \& Bayat, M.S., 2007, A guide to managing research, Juta and Co. Ltd, Cape Town.

Fuller, A., 2007, Tricky kid, Finch Publishers, Sydney.

Ganga, C., 2007, The Tik off campaign launched today, viewed 15 August 2007, from http://bushradionews.blogspot.com/2007_07_01_archive.html

Gordon, S.M., 2003, Relapse - Removing the taboos on the topic and promoting honest efforts to address it, Caron Foundation, Wernersville.

Jarvis, T.J., Tebutt, J., Mattick, R.P. \& Sand, F., 2005, Treatment approaches for alcohol and drug dependence: An introductory guide, 2nd edn., John Wiley and Sons Ltd Bognor Regis.

Johnson, B. \& Lazarus, S., 2008, 'The role of schools in building the resilience of youth faced with adversity', Journal of Psychology in Africa 18(1), 19-30.

Keegan, K. \& Moss, H.B., 2008, Chasing the high, Oxford University Press, Philadelphia.

Krefting, L., 1991, 'Rigor in qualitative research: The assessment of trustworthiness' American Journal of Occupational Therapy 45(3), 214-222. http://dx.doi. American Journal of Occupational Ther
org/10.5014/ajot.45.3.214, PMid:2031523

Lessa, N.R. \& Scanlon, W.F., 2006, Concise guide to mental health: Substance use disorders, John Wiley and Sons Ltd, Hoboken. PMCid:1325005

Louw, D. \& Louw, A., 2007, Child and adolescent development, University of the Free State, Bloemfontein.

Mans, P., 2000, Dwelms: Word straatwys oor dwelm, Lux Verbi, Cape Town.

Meyer, R., 2005, 'Towards a rational approach to substance abuse behaviour', Continuing Medical Education 23(6), 290-293.

National Institute on Drug Abuse, 2006, National survey on drug use, United States Department of Health and Human Sciences, Washington, DC.

Neuland, L., 2006, How to win when life is unfair: Emotional intelligence, Larné Publishing, Pretoria. PMid:16646980, PMCid:1526634

Njuho, P. \& Davids, A., 2010, 'Extent and influence of recreational drug use on men and women aged 15 years and older in South Africa', African Journal of Drug and Alcohol Studies 9(1), 33-48. http://dx.doi.org/10.4314/ajdas.v9i1.68394

Noyoo, N., Patel, L. \& Loffell, J., 2006, The human development situation of Johannesburg's youth, Professional Journal for Social Work 42(1), 93-100.

Page, R.M. \& Page, T.S., 2003, Fostering emotional well-being in the classroom, 3rd edn., Jones and Bartlett Publishers, Sudbury.

Pienaar, J., 2006, 'Kaapstad = Tikhoofstad', Die Burger, 27 December, p. 4.

Republic of South Africa, 2008, Prevention of and Treatment for Substance Abuse Act (Act No. 70 of 2008), Government Printers, Pretoria.

Rosenberg, L., 2008, 'To preserve, strengthen and expand America's mental health and addictions treatment capacity', Journal of Behavioural Health Services and Research 35(3), 237-239. http://dx.doi.org/10.1007/s11414-008-9137-z, PMid:18575983

Saleeby, D., 2006, Strengths perspective in social work practice, 4th edn., Allyn and Bacon Publishers, Boston. PMid:16725298

Sheafor, B.W. \& Horejsi, C.R., 2006, Techniques and guidelines for social work practice, 7 th edn., Pearson Education Ltd, Boston. PMid:16895797

South African Community Epidemiology Network on Drug Use, 2010, News update, Medical Research Council, Cape Town.

Straussner, S.L.A. \& Fewell, C.H., 2006, Impact of substance abuse of children and families: research and practice implications, Haworth Press, New York. 
Taleff, M.J., 2006, Critical thinking for addiction professionals, Springer Publishing Company, New York. PMid:17140396

United Nations Office on Drugs \& Crime, 2002, Ke-Moya - I'm fine without drugs, Miles and Associates International, Pretoria.

United Nations, 2003, Economic and social commission for Asia and the Pacific United Nations: Office on drugs and crime, United Nations Publications, New York.

Van Den Berg, H., 2003, "n Nasorgprogram vir maatskaplike werkers vir die behandeling van substansafhanklike adolessente', unpublished MA dissertation, Department of Social Work, University of Pretoria.

Van Der Westhuizen, M.A., 2007, 'Relapsing after treatment: Exploring the experiences of chemically addicted adolescents', unpublished MA dissertation, Department of Social work, University of South Africa.
Van Der Westhuizen, M.A., 2010, 'Aftercare to chemically addicted adolescents: practice guidelines from a Social Work perspective', unpublished DPhil dissertation, Department of Social Work, University of South Africa, Pretoria.

Walliman, N., 2001, Your research project, Sage Publications, Thousand Oaks.

World Health Organization, 2008, Principles of Drug Dependence Treatment, WHO Geneva.

Youth at the United Nations, 2006, Guide to the implementation of the world programme of action for youth, Department of Economic and Social Affairs of the United Nations, New York.

Zulu, X., 2006., Youth turns to drugs as sales at schools soar, viewed 02 June 2006 from http://www.iol.co.za/news/south-africa/youth-turn-to-drugs-as-sales-atschools-soar-1.269653 